\title{
Isolation of the Spermatogonial Stem Cell-Containing Fraction from Testes
}

\author{
Shaun Goodyear and Ralph Brinster
}

\begin{abstract}
A testis cell fraction enriched for spermatogonial stem cells (SSCs) compared with the unfractionated total testis cell population can be isolated from testes after birth and adult stages. This protocol involves dissociating the seminiferous tubules into a single-cell suspension, using enzymes and mechanical disruption. This is followed by the selection of the Thy $1^{+}$cell fraction that contains nearly the entire SSC population and is enriched for these cells compared with the total testis cell population. This isolated fraction can be used for molecular studies, transfer into culture to establish primary cultures, or transplantation into the testes of recipients for spermatogenesis. Typically, if the SSCs are destined for transplantation, a marker is included to visualize the clones of spermatogenesis (e.g., lac $Z$ or green fluorescent protein [GFP] transgenes). It is important to note that the isolated Thy $1^{+}$cell fraction does not consist of pure SSCs and that most germ cells are non-stem-cell progenitors, and a smaller portion of the population is somatic cells.
\end{abstract}

\section{MATERIALS}

It is essential that you consult the appropriate Material Safety Data Sheets and your institution's Environmental Health and Safety Office for proper handling of equipment and hazardous materials used in this protocol.

\section{Reagents}

Animals: postnatal male mice, up to 2 mo of age

The preferred age is 6-8 d old, which produces the greatest enrichment of SSCs.

Collagenase solution $(1 \mathrm{mg} / \mathrm{mL}$ in HBSS $)$

DNase I solution $(7 \mathrm{mg} / \mathrm{mL}$ in HBSS $)$

Fetal bovine serum (FBS)

Hanks' balanced salt solution (HBSS), $\mathrm{Ca}^{2+} / \mathrm{Mg}^{2+}$ free

Mitomycin C medium (10 $\mu \mathrm{g} / \mathrm{mL}$ in DMEM growth medium)

PBS-S (PBS with 1\% FBS, $10 \mathrm{~mm}$ HEPES, $1 \mathrm{~mm}$ pyruvate, $1 \mathrm{mg} / \mathrm{mL}$ glucose, 50 units/mL penicillin, and $50 \mu \mathrm{g} / \mathrm{mL}$ streptomycin) ( $\mathrm{pH} 7.6)$

Percoll solution (30\%) (phosphate-buffered saline [PBS] with 1\% FBS, 50 units/mL penicillin, $50 \mu \mathrm{g} / \mathrm{mL}$ streptomycin, and 30\% Percoll)

Serum-free medium (SFM) (minimum essential medium- $\alpha$ or F10 medium [Invitrogen] with $0.2 \%$ bovine serum albumin [BSA], Fraction V catalog no. 810661, Lot 7839H, MP Biomedicals, $5 \mu \mathrm{g} / \mathrm{mL}$ insulin [Sigma-Aldrich], $10 \mu \mathrm{g} / \mathrm{mL}$ iron-saturated transferrin [Sigma-Aldrich], 7.6 $\mu \mathrm{Eq} / \mathrm{L}$ free fatty

From the Manipulating the Mouse Embryo collection, edited by Richard Behringer, Marina Gertsenstein, Kristina Vintersten Nagy, and Andras Nagy.

(C) 2017 Cold Spring Harbor Laboratory Press

Cite this protocol as Cold Spring Harb Protoc; doi:10.1101/pdb.prot094185 
S. Goodyear and R. Brinster

acids, $3 \times 10^{-8} \mathrm{M} \mathrm{H}_{2} \mathrm{SeO}_{3}$ [Sigma-Aldrich], $50 \mu \mathrm{m}$ 2-mercaptoethanol, $10 \mathrm{~mm}$ HEPES, and $60 \mu \mathrm{m}$ putrescine [Sigma-Aldrich], $2 \mathrm{~mm}$ glutamine, and antibiotics [penicillin at $50 \mathrm{units} / \mathrm{mL}$ and streptomycin at $50 \mu \mathrm{g} / \mathrm{mL}]$ )

Free fatty acids comprise palmitic, palmitoleic, stearic, oleic, linoleic, and linolenic acids (all Sigma-Aldrich) in the respective millimolar proportions of 31.0:2.8:11.6:13.4:35.6:5.6 for $100 \mathrm{mEq} / \mathrm{L}$ stock solution (see Kubota et al. $2004 a, b)$.

Thy1 antibody-conjugated microbeads (anti-mouse CD90 [Thy1.2]; Miltenyi Biotech catalog no. 130-049-101)

Trypsin-EDTA (0.25\% trypsin, 1 mм EDTA)

Equipment

Cell strainer (40- $\mu \mathrm{m}$ pore size) (Corning Lifescience catalog no. 352340)

Centrifuge, refrigerated

Centrifuge tubes (15 and $50 \mathrm{~mL}$ ), conical

Magnetic-activated cell sorting (MACS) apparatus (Miltenyi Biotec catalog no. 130-090-312) and

MACS columns (Miltenyi Biotec catalog no. 130-042-201)

Serological pipettes $(5 \mathrm{~mL})$

\section{METHOD}

Testis Disaggregation

1. Collect testes in sterile HBSS using aseptic technique and remove the tunica albuginea.

For Pup Testes

i. Place the tissue in $4.5 \mathrm{~mL}$ of trypsin-EDTA solution, and add $0.5 \mathrm{~mL}$ of DNase I solution.

ii. Incubate for $5 \mathrm{~min}$ at $37^{\circ} \mathrm{C}$. Pipette gently to disperse the tubules, and add another $0.5 \mathrm{~mL}$ of DNase I solution.

iii. Continue the digestion at $37^{\circ} \mathrm{C}$ for another $5 \mathrm{~min}$. Add $1 \mathrm{~mL}$ of FBS and a final $0.5 \mathrm{~mL}$ of DNase I solution.

iv. Pipette the mixture to generate a single-cell suspension. Add more DNase I solution if needed.

v. Pass the cell suspension through a 40- $\mu \mathrm{m}$-pore-size cell strainer and wash with HBSS.

vi. Pellet the cells by centrifugation at $600 \mathrm{~g}$ for $7 \mathrm{~min}$ at $4^{\circ} \mathrm{C}$.

\section{For Adult Testes}

i. Place each testis into $10 \mathrm{~mL}$ of collagenase solution $(1 \mathrm{mg} / \mathrm{mL}$ in HBSS $)$ in a $50-\mathrm{mL}$ conical tube, and add $1 \mathrm{~mL}$ of DNase I solution.

ii. Incubate at $37^{\circ} \mathrm{C}$ with gentle swirling every $2-5$ min until the seminiferous tubules have completely separated.

iii. Add $5 \mathrm{~mL}$ of HBSS, and place the separated tubules on ice for $5 \mathrm{~min}$ to allow for sedimentation by gravity.

iv. Remove the supernatant without disrupting the tubule sediment, and add another $10 \mathrm{~mL}$ of HBSS. Swirl to wash the tubules, and set on ice for $5 \mathrm{~min}$ to allow the tubules to resediment.

v. Repeat washing and sedimenting of the tubules three times.

These steps are necessary to remove the interstitial cells.

vi. After removing the supernatant for the last time, resuspend the tubules in $5 \mathrm{~mL}$ of trypsinEDTA solution, and add $0.5 \mathrm{~mL}$ of DNase I solution. 


\section{Percoll Isolation}

vii. Incubate for $5 \mathrm{~min}$ at $37^{\circ} \mathrm{C}$. Add $1 \mathrm{~mL}$ of FBS and a final $0.5 \mathrm{~mL}$ of DNase I solution.

viii. Pipette to generate a single-cell suspension. Add more DNase solution if needed.

ix. Pass the cell suspension through a $40-\mu \mathrm{m}$-pore-size cell strainer, and wash with HBSS.

$\mathrm{x}$. Pellet the cells by centrifugation at $600 \mathrm{~g}$ for $7 \mathrm{~min}$ at $4^{\circ} \mathrm{C}$.

2. After centrifugation, remove the supernatant and resuspend the cell pellet in $10 \mathrm{~mL}$ of HBSS. Determine the cell concentration. Use HBSS to dilute the cell suspension to a maximum cell count of $20 \times 10^{6}$ per $5 \mathrm{~mL}$ of volume.

3. Slowly layer $5 \mathrm{~mL}$ of the cell suspension on top of $2 \mathrm{~mL}$ of a $30 \%$ Percoll solution in $15-\mathrm{mL}$ conical centrifuge tubes.

It is useful to tilt the tube at an angle while pipetting to minimize mixing of the cell suspension with the Percoll solution.

4. Centrifuge at $600 \mathrm{~g}$ for $8 \mathrm{~min}$ at $4^{\circ} \mathrm{C}$.

5. Remove the top solution phases (HBSS and Percoll), and resuspend the cell pellets within each tube in $2 \mathrm{~mL}$ of PBS-S.

6. Combine the resuspended cell suspensions from all tubes and determine the cell concentration. A typical recovery after Percoll selection is $60 \%-80 \%$ of the cells.

7. Dilute the cell suspension to provide $5 \times 10^{6}$ or less cells $/ \mathrm{mL}$. Place $1 \mathrm{~mL}$ of cell suspension into separate $15-\mathrm{mL}$ conical tubes.

8. Pellet the cells by centrifugation at $600 \mathrm{~g}$ for $7 \mathrm{~min}$ at $4^{\circ} \mathrm{C}$.

9. Remove the supernatant, and resuspend the pellet in $180 \mu \mathrm{L}$ of PBS-S $\left(5 \times 10^{6}\right.$ cells or less $)$.

\section{Thy $1^{+}$Selection by Magnetic-Activated Cell Sorting}

10. Add Thyl antibody-conjugated microbeads to the pelleted cells resuspended in PBS-S at a dilution of 1:10, and mix gently. Incubate for $20 \mathrm{~min}$ at $4^{\circ} \mathrm{C}$, mixing after $10 \mathrm{~min}$ (follow the manufacturer's instructions).

11. Add an additional volume of $2 \mathrm{~mL}$ of PBS-S, and pellet the cells by centrifugation at $600 \mathrm{~g}$ for 7 min at $4^{\circ} \mathrm{C}$. Resuspend the pellet in $1 \mathrm{~mL}$ of PBS-S.

12. Set up the MACS columns and prewash them with $0.5 \mathrm{~mL}$ of PBS-S. Add the Thy1-labeled cell suspension.

The number of columns needed is determined on the basis of the total cell number, as described by the manufacturer. Typically, only one column is needed for a preparation involving the testes of eight to 10 mouse pups that are $6 \mathrm{~d}$ old.

13. After the suspension has passed through the column, wash it three times with $0.5 \mathrm{~mL}$ of PBS-S, and elute the Thyl ${ }^{+}$cells from the column in $1 \mathrm{~mL}$ of SFM.

14. Pellet the cells by centrifugation $\left(600 \mathrm{~g}\right.$ for $7 \mathrm{~min}$ at $\left.4^{\circ} \mathrm{C}\right)$. Resuspend the cell pellet in $1 \mathrm{~mL}$ of SFM and determine the cell concentration. A typical yield should be $\sim 20 \times 10^{4}-25 \times 10^{4} \mathrm{Thy}^{+}$cells $^{4}$ per testis from a 6-d-old pup.

When viewed with a microscope, the freshly isolated cell population should be relatively homogeneous; $80 \%-90 \%$ of the cells should be large, spherical germ cells, and $70 \%$ of these should be Thy $1^{+}$spermatogonia (Kubota et al. 2003; 2004a, b).

\section{RELATED INFORMATION}

Methods for culture and transplantation of SSCs are described in Protocol: Culture and Expansion of Primary Undifferentiated Spermatogonial Stem Cells (Goodyear and Brinster 2017a) and in Proto- 
col: Spermatogonial Stem Cell Transplantation to the Testis (Goodyear and Brinster 2017b), respectively.

\section{ACKNOWLEDGMENTS}

The authors acknowledge Jon Oatley for helpful comments.

\section{REFERENCES}

Goodyear S, Brinster R. 2017a. Culture and expansion of primary undifferentiated spermatogonial stem cells. Cold Spring Harb Protoc doi: 10.1101/pdb.prot094193.

Goodyear S, Brinster R. 2017b. Spermatogonial stem cell transplantation to the testis. Cold Spring Harb Protoc doi: 10.1101/pdb.prot094235.

Kubota H, Avarbock MR, Brinster RL. 2003. Spermatogonial stem cells share some, but not all, phenotypic and functional characteristics with other stem cells. Proc Natl Acad Sci 100: 6487-6492.
Kubota H, Avarbock MR, Brinster RL. 2004a. Culture conditions and single growth factors affect fate determination of mouse spermatogonial stem cells. Biol Reprod 71: 722-731.

Kubota H, Avarbock MR, Brinster RL. 2004b. Growth factors essential for self-renewal and expansion of mouse spermatogonial stem cells. Proc Natl Acad Sci 101: 16489-16494. 


\section{Isolation of the Spermatogonial Stem Cell-Containing Fraction from Testes}

Shaun Goodyear and Ralph Brinster

Cold Spring Harb Protoc; doi: 10.1101/pdb.prot094185

\begin{tabular}{|c|c|}
\hline $\begin{array}{r}\text { Email Alerting } \\
\text { Service }\end{array}$ & Receive free email alerts when new articles cite this article - click here. \\
\hline $\begin{array}{l}\text { Subject } \\
\text { Categories }\end{array}$ & $\begin{array}{l}\text { Browse articles on similar topics from Cold Spring Harbor Protocols. } \\
\text { Mouse ( } 437 \text { articles) } \\
\text { Stem Cells ( } 46 \text { articles) } \\
\text { Stem Cells, general ( } 70 \text { articles) }\end{array}$ \\
\hline
\end{tabular}

